\title{
List of Abbreviations and Glossary
}

ansambl': a coordinated set of architectural features or complex of buildings (from the French ensemble), a key term in city planning through the Soviet period.

Antonov and Kobak, SSPb: V. V. Antonov and A. V. Kobak, Sviatyni SanktPeterburga: Entsiklopediia khristianskikh khramov, 3rd ed. (St. Petersburg: Fond Spas, 2010).

ASPbE: Arkhiv Sankt-Peterburgskoi eparkhii (St. Petersburg Diocesan Archive).

ASPbGASU: Archive of SPbGASU (see below).

BAN: Biblioteka Akademii Nauk (Library of the Academy of Sciences, St. Petersburg).

blagolepie: a Church Slavonic term signifying decorum, good order.

chapel (chasovnia): a freestanding chapel, e.g., in a street.

Church Council (Vserossiiskii Pomestnyi Sobor): the All-Russian Local (as opposed to Ecumenical) Council of the Orthodox Church held in Moscow from 1917 to 1918.

Coreligionists (Edinovertsy): A body of the Orthodox faithful who, while celebrating rites according to the practices of the Old Believers, have since 1800 been in communion with the mainstream Orthodox Church.

diocese (eparkhiia): An ecclesiastical territory under the jurisdiction of a bishop or metropolitan (metropolitan bishop). The diocese of which Petrograd/ Leningrad was the center was known from August 18, 1914, to June 17, 1917, as the Diocese of Petrograd and Ladoga, from then until January 1924 as the Diocese of Petrograd and Gdov, from 1924 until 1943 as the Diocese of Leningrad and Gdov, from 1943 to 1957 as the Diocese of Leningrad and Novgorod, and from 1957 until 1991 as the Diocese of Leningrad and Ladoga. 
It is now the Diocese of St. Petersburg and Ladoga. For the sake of brevity I refer here to "Petrograd diocese" and "Metropolitan of Leningrad," etc.

DSV: Dekrety sovetskoi vlasti: (Moscow: Institut marksizma-leninizma, 1957-)

dvadtsatka: The group of at least twenty worshippers forming a congregation or community (obshchina) for the purposes of leasing a place of worship and so on under the statute of January 20, 1918, and throughout the Soviet period.

FN: author's field notes.

funerary chapel (usypal'nitsa): a memorial structure, e.g., in a cemetery.

GARF: Gosudarstvennyi arkhiv Rossiiskoi Federatsii (State Archive of the Russian Federation)

GMISPb: Gosudarstvennyi muzei istorii Sankt-Peterburga (State Museum of St. Petersburg).

GIOP: Gosudarstvennaia inspektsiia okhrany pamiatnikov (State Inspectorate for the Protection of Monuments)

Gorkom: Gorodskoi komitet Kommunisticheskoi partii Sovetskogo Soiuza (City Committee of the Communist Party), the primary organ of Party rule in Leningrad city, subordinate to the Obkom.

house church (domovaia tserkov'): a "chapel" in the sense of an institutional or domestic place of worship, whether inside a building or freestanding.

incumbent (nastoiatel'): the senior cleric in a church or cathedral, roughly equivalent to "rector" or "vicar" in the Anglican Church and "parish priest" in the Roman Catholic Church, in the first case, and "dean" in the second.

$K G$ : Krasnaia gazeta.

Lengubsovet: Leningradskii gubernskii sovet rabochikh, krest'ianskikh i krasnoarmeiskikh deputatov, the Council of Deputies, or main organ of government for Leningrad Province, 1924-1927.

Lenispolkom: Ispolnitel'nyi sovet Leningradskogo soveta deputatov trudiashchikhsia: the Executive Committee of Lensovet (see below).

Lenoblispolkom: Ispolnitel'nyi komitet Leningradskogo oblastnogo soveta deputatov trudiashchikhsia: the Executive Committee of Lenoblsovet (see below). 
Lenoblsovet: Leningradskii oblastnoi sovet rabochikh, krest'ianskikh i krasnoarmeiskikh deputatov (later deputatov trudiashchikhsia and then narodnykh deputatov), the Council of Deputies, or main organ of government, for Leningrad Province, 1927-1991.

Lensovet: Leningradskii sovet rabochikh, krest'ianskikh i krasnoarmeiskikh deputatov (later deputatov trudiashchikhsia and then narodnykh deputatov), the Council of Deputies, or main organ of municipal government, 1924-1991.

liniia: a term occasionally used for streets in St. Petersburg, particularly on Vasilievskii Island.

LISI: Leningradskii inzhinerno-stroitel'nyi institut (the Leningrad Institute of Civil Engineering and Construction), previously the Institute of Civil Engineers, founded 1832, the training place for most of Leningrad's planners from the mid-1930s.

LOSA: Leningradskoe otdelenie Soiuza arkhitektorov (the Leningrad branch of the Union of Architects).

LP: Leningradskaia pravda.

NA UGIOP: Nauchnyi arkhiv Upravleniia Gosudarstvennoi inspektsii okhrany pamiatnikov (Scholarly Archive of the Board of Management of the State Inspectorate for the Preservation of Monuments, St. Petersburg).

NEP: Novaia ekonomicheskaia politika (New Economic Policy, or period of limited license for private enterprise, 1921-1928).

Obkom: Oblastnoi komitet Kommunisticheskoi partii Sovetskogo Soiuza (Provincial Committee of the Communist Party), the primary organ of Party rule at regional level (superior to the Gorkom).

OPIK 1973: Anisimov, G. G., ed. Okhrana pamiatnikov istorii i kultury; Sbornik dokumentov. Moscow: Sovetskaia Rossiia, 1973.

OR RNB: Otdel rukopisei Rossiiskoi natsional'noi biblioteki (Manuscript Department of the Russian National Library).

parish (prikhod): a territorial subdivision of a diocese; traditionally, the community associated with a church in geographical terms; in the Soviet period, the members of the "religious society." 
pereulok: a side street.

Petrogubsovet: Petrogradskii Gubernskii Sovet rabochikh, krest'ianskikh i soldatskikh deputatov, the highest organ of administration in Petrograd province, 1917-1924.

Petrosovet: Petrogradskii Sovet rabochikh i soldatskikh deputatov (Petrograd City Council), the highest organ of the city administration, 1917-1924.

ploshchad': a city square.

PP: Petrogradskaia pravda.

prospekt: avenue, a major street.

PSZ: Polnoe sobranie zakonov Rossiiskoi Imperii (St Petersburg: Tipografiia Sobstvennoi Ego Velichestva Kantseliarii, 1830-1884; Gosudarstvennaia tipografiia, 1885-1916).

RA IIMK: Rukopisnyi arkhiv Instituta material'noi kul'tury Rossiiskoi Akademii Nauk (Manuscript Archive of the Institute of Material Culture, Russian Academy of Sciences, St. Petersburg).

RGANI: Rossiiskii gosudarstvennyi arkhiv noveishei istorii (Russian State Archive of Recent History, Moscow).

RGB: Rossiiskaia gosudarstvennaia biblioteka (Russian State Library, former Lenin Library, Moscow).

RNB: Rossiiskaia natsional'naia biblioteka (Russian National Library, former Public Library, St. Petersburg).

RO IRLI RAN: Rukopisnyi otdel Instituta russkoi literatury Rossiiskoi Akademii Nauk (Manuscript Section of the Institute of Russian Literature, Russian Academy of Sciences, St. Petersburg).

RSFSR: Rossiiskaia Sovetskaia Federativnaia Sotsialisticheskaia Respublika (Russian Soviet Federal Socialist Republic), the official title of what is now the Russian Federation under Soviet rule. Unlike the other Soviet republics, the RSFSR did not have a separate government or central committee of the Communist Party, but it did have its own ministries, responsible, among other things, for aspects of conservation policy. 
Sovnarkom: Sovet narodnykh komissarov (The Council of People's Commissars), the main government (as opposed to Party) organ of executive government in the USSR (replaced by the Council of Ministers [Sovet ministrov] in 1946).

SPbGASU: Sankt-Peterburgskii gosudarstvennyi arkhitekturno-stroitel'nyi universitet (the St. Petersburg State University of Architecture and Construction) (formerly LISI).

SU: Sobranie uzakonenii i rasporiazhenii raboche-krest'ianskogo pravitel'stva (Moscow: Narodnyi komissariat iustizii, 1919-)

TsGA-SPb: Tsentral'nyi gosudarstvennyi arkhiv Sankt-Peterburga (Central State Archive of St. Petersburg).

TsGAIPD-SPb: Tsentral'nyi gosudarstvennyi arkhiv istoriko-politicheskikh dokumentov Sankt-Peterburga (Central State Archive of Historico-Political Documents, St. Petersburg).

TsGAKFFD-SPb: Tsentral'nyi gosudarstvennyi arkhiv kino- foto- fonodokumentov Sankt-Peterburga (State Archive of Film, Photographic, and Phonographic Documents, St. Petersburg).

TsGALI-SPb: Tsentral'nyi gosudarstvennyi arkhiv literatury i iskusstva SanktPeterburga (Central State Archive of Literature and Art, St. Petersburg).

TsGANTD-SPb: Tsentral'nyi gosudarstvennyi arkhiv nauchno-tekhnicheskoi dokumentatsii Sankt-Peterburga (Central State Archive of Scientific and Technical Documentation, St. Petersburg).

ulitsa: a street.

$V L$ : Vechernii Leningrad. 